\title{
A-Site Effect on the Conversion of Bio-Ethanol into Isobutene over Ternary $\mathrm{A}_{1} \mathrm{Zn}_{\mathrm{y}} \mathrm{Zr}_{\mathrm{z}} \mathrm{O}_{\mathrm{n}}$ Catalysts
}

\author{
Feng Liu, Yong Men*, Jinguo Wang, Xiaoxiong Huang, Biao Zhao, Rong He \\ College of Chemistry and Chemical Engineering, Shanghai University of Engineering Science, Shanghai, China \\ Email: *men@sues.edu.cn
}

Received 19 May 2016; accepted 17 July 2016; published 20 July 2016

Copyright (C) 2016 by authors and Scientific Research Publishing Inc.

This work is licensed under the Creative Commons Attribution International License (CC BY). http://creativecommons.org/licenses/by/4.0/

(c) (7) Open Access

\begin{abstract}
Ternary multifunctional $\mathrm{A}_{1} \mathrm{Zn}_{\mathrm{y}} \mathrm{Zr}_{\mathrm{z}} \mathrm{O}_{\mathrm{n}}$ catalysts are prepared by introducing A-site transition metals with the redox capability into binary $\mathrm{Zn}_{1} \mathrm{Zr}_{8} \mathrm{O}_{\mathrm{n}}$. Structure and morphology were investigated by means of XRD, BET and FESEM, respectively. Activity data showed that $\mathrm{Cr}$ addition exhibited obvious beneficial effect to promote isobutene production from direct conversion of bio-ethanol compared to other A-site metal dopants. A significant higher yield of isobutene over Cr-promoted $\mathrm{Zn}_{1} \mathrm{Zr}_{8} \mathrm{O}_{\mathrm{n}}$ catalyst was also observed with respect to its binary $\mathrm{Zn}_{1} \mathrm{Zr}_{8} \mathrm{O}_{\mathrm{n}}$ counterpart. The choice of A-site metal is of prime importance in the isobutene production, catalyzing mainly the ethanol dehydrogenation, meanwhile the appropriate addition of zinc on the catalyst surface is also essential for good isobutene yield.
\end{abstract}

\section{Keywords}

$\mathrm{A}_{1} \mathrm{Zn}_{1} \mathrm{Zr}_{8} \mathrm{O}_{\mathrm{n}}$, Bio-Ethanol to Isobutene, Multifunctional Catalysts, The Redox Capability, Dehydrogenation

\section{Introduction}

Conversions from sustainable biomass-based raw materials to valuable fuels and chemicals have drawn intensive interest to meet grand challenges in global warming and depletion of fossil feedstocks [1] [2]. With the development of biological fermentation, bio-ethanol has become the major product from biomass conversion [3] [4]. Currently, bio-ethanol conversions to highly valuable chemicals are mainly focused on ethanol dehydration to ethylene over solid acid catalysts, such as alumina [5], zeolites [6] and heteropoly acids [7] or ethanol dehy-

\footnotetext{
*Corresponding author.
}

How to cite this paper: Liu, F., Men, Y., Wang, J.G., Huang, X.X., Zhao, B. and He, R. (2016) A-Site Effect on the Conversion of Bio-Ethanol into Isobutene over Ternary $\mathrm{A}_{1} \mathrm{Zn}_{\mathrm{y}} \mathrm{Zr}_{\mathrm{z}} \mathrm{O}_{\mathrm{n}}$ Catalysts. Modern Research in Catalysis, 5, 95-101. 
drogenation to acetaldehyde and then to acetone viaaldol-condensation routes [8]. In particular, bio-ethanol conversion to lighter olefins has become a strategic reaction for the production of highly valuable chemicals. At present, isobutene is predominantly produced via extractive distillation of the $\mathrm{C}_{4}$ fraction from catalytic steam cracking of fossil-based naphtha in ethylene production. With the switching to shale gas for industrial production of ethylene, it calls for alternative methods of $\mathrm{C}_{4}$ light olefins synthesis. Therefore, it is highly desirable to explore new routes to produce isobutene from renewable resources.

Tago et al. [9] found that alkali metal ion-exchanged BEA zeolites exhibited the high yield (55\%) of acetone conversion to isobutene as a result of elimination of the strong acidic sites by introduced alkali metal ions (Na, $\mathrm{K}, \mathrm{Rb}$ and $\mathrm{Cs}$ ) and inhibition of the formation of aromatics and coke. Wang and co-workers reported the first evidence of direct conversion of bio-ethanol to isobutene (ETIB) over $\mathrm{Zn}_{\mathrm{x}} \mathrm{Zr}_{\mathrm{y}} \mathrm{O}_{\mathrm{z}}$ mixed oxide catalyst [10]. They rationalized that the balanced acid-base sites of $\mathrm{Zn}_{\mathrm{x}} \mathrm{Zr}_{\mathrm{y}} \mathrm{O}_{\mathrm{z}}$ were responsible for the direct and high-yield conversion of ETIB. The direct one-step conversion of ethanol to value-added $\mathrm{C}_{4}$ light olefins has long been the target of catalysis research [11]. $\mathrm{SiO}_{2}-\mathrm{MgO}$ mixed oxides have been found to be active for one-step conversion of ethanol to 1,3-butadiene, and with various dopants introduced, such as $\mathrm{Cu}$ [12], $\mathrm{Ag}$ [13], and other transition metal (oxide)s [14]. The catalytic properties of the binary $\mathrm{SiO}_{2}-\mathrm{MgO}$ system can be enhanced by promoting the dehydrogenation of ethanol and by shifting the rate-relevant step of the reaction network.

In this work, different A-site metals such as $\mathrm{Fe}$, $\mathrm{Cr}$, and Ni were introduced into binary $\mathrm{Zn}_{1} \mathrm{Zr}_{8} \mathrm{O}_{\mathrm{n}}$ forming ternary $\mathrm{A}_{1} \mathrm{Zn}_{1} \mathrm{Zr}_{8} \mathrm{O}_{\mathrm{n}}$ composite catalysts, aiming to enhance the catalytic activity for ETIB reaction. Our results show that by introducing $\mathrm{Cr}$, the selectivity of isobutene formation over ternary $\mathrm{Cr}_{1} \mathrm{Zn}_{1} \mathrm{Zr}_{8} \mathrm{O}_{\mathrm{n}}$ mixed oxide composite is markedly increased compared to that of binary $\mathrm{Zn}_{1} \mathrm{Zr}_{8} \mathrm{O}_{\mathrm{n}}$. Meanwhile, the contents of zinc and zirconium species were found to be essential for the isobutene production over ternary $\mathrm{Cr}_{1} \mathrm{Zn}_{\mathrm{y}} \mathrm{Zr}_{\mathrm{z}} \mathrm{O}_{\mathrm{n}}$.

\section{Experimental}

\subsection{Preparation of Ternary $\mathrm{A}_{1} \mathrm{Zn}_{\mathrm{y}} \mathrm{Zr}_{\mathrm{z}} \mathrm{O}_{\mathrm{n}}$ Catalysts}

To synthesize ternary $\mathrm{A}_{1} \mathrm{Zn}_{\mathrm{y}} \mathrm{Zr}_{\mathrm{z}} \mathrm{O}_{\mathrm{n}}$ catalysts, we employed the conductive carbon black $\mathrm{T} 100$ as the hard template, which was heated at $180^{\circ} \mathrm{C}$ overnight before being used. In a typical synthesis, $0.00125 \mathrm{~mol}$ of $\mathrm{Zn}\left(\mathrm{NO}_{3}\right)_{2} \cdot 6 \mathrm{H}_{2} \mathrm{O}$ (Sigma-Aldrich, $>99.8 \%$ ), $0.01 \mathrm{~mol}$ of $\mathrm{ZrO}\left(\mathrm{NO}_{3}\right)_{2} \cdot \mathrm{xH}_{2} \mathrm{O}$ (Sigma-Aldrich, $>99.8 \%$ ), and $0.00125 \mathrm{~mol}$ of $\mathrm{Ni}\left(\mathrm{NO}_{3}\right)_{2} \cdot 3 \mathrm{H}_{2} \mathrm{O}$ (Sigma-Aldrich, >99.8\%) were dissolved in $40 \mathrm{ml}$ de-ionized water with ultrasonic treatment for 30 mins to obtain a clear and homogeneous solution. Then, $6.0 \mathrm{~g}$ of preheated MA100 (Mitsubishi, Japan) was added into the above solution with stirring at the speed of 500 RPM for 2.0 hrs. After that, the mixture was transferred to a ceramic crucible and dried at $110^{\circ} \mathrm{C}$ for $12 \mathrm{hrs}$ in oven and further calcined at $400^{\circ} \mathrm{C}$ for 4.0 hrs and stay at $550^{\circ} \mathrm{C}$ for another $20 \mathrm{hrs}$ to remove the carbon black. The obtained white powders were denoted as $\mathrm{Ni}_{1} \mathrm{Zn}_{1} \mathrm{Zr}_{8} \mathrm{O}_{\mathrm{n}}$ catalysts. When $\mathrm{Ni}\left(\mathrm{NO}_{3}\right)_{2} \cdot 3 \mathrm{H}_{2} \mathrm{O}$ was replaced by $\mathrm{Fe}\left(\mathrm{NO}_{3}\right)_{3} \cdot 9 \mathrm{H}_{2} \mathrm{O}, \mathrm{Co}\left(\mathrm{NO}_{3}\right)_{2} \cdot 3 \mathrm{H}_{2} \mathrm{O}$ or $\mathrm{Cr}\left(\mathrm{NO}_{3}\right)_{3} \cdot 9 \mathrm{H}_{2} \mathrm{O}$, $\mathrm{Fe}_{1} \mathrm{Zn}_{1} \mathrm{Zr}_{8} \mathrm{O}_{\mathrm{n}}, \mathrm{Co}_{1} \mathrm{Zn}_{1} \mathrm{Zr}_{8} \mathrm{O}_{\mathrm{n}}$ or $\mathrm{Cr}_{1} \mathrm{Zn}_{1} \mathrm{Zr}_{8} \mathrm{O}_{\mathrm{n}}$ composite oxide was obtained, respectively.

\subsection{Catalyst Characterizations}

Several physical techniques were employed to characterize the structure of synthesized catalysts. a) X-ray powder diffraction patterns (XRD) for all the samples were collected on X-ray diffractometer. b) Morphology and size of $\mathrm{Cr}_{1} \mathrm{Zn}_{1} \mathrm{Zr}_{8} \mathrm{O}_{\mathrm{n}}$ catalyst were probed by field emission scanning electron microscopy (FESEM, Hitachi S4800). c) Nitrogen adsorption-desorption isotherms were recorded on a Micromeritics ASAP 2460 at $77 \mathrm{~K}$, where the specific surface areas $\left(S_{\mathrm{BET}}\right)$, pore volume $\left(V_{\mathrm{P}}\right)$ and pore diameter $\left(D_{\mathrm{P}}\right)$ were calculated by applying the Brunauer-Emmett-Teller (BET) and Barrett-Joyner-Halenda (BJH) models to the desorption branches.

\subsection{Catalytic Activity Measurements}

The vapor-phase ETIB reactions were evaluated in a tubular quartz reactor (i.d. $5.0 \mathrm{~mm}$ ). In each run, $200 \mathrm{mg}$ catalyst pelletized catalyst sample (size range: 40 - 60 mesh) was placed at the center of the reactor tube between two layers of quartz wool and were pretreated in $\mathrm{N}_{2}(50 \mathrm{ml} / \mathrm{min})$ at $400^{\circ} \mathrm{C}$ for $0.5 \mathrm{~h}$. A mixture of ethanol $/ \mathrm{H}_{2} \mathrm{O}$ (steam/carbon ratio $=5.0$ ) was then introduced into the evaporator $\left(200^{\circ} \mathrm{C}\right)$ by a syringe pump and directly carried into the reaction system by flowing carrier gas of $\mathrm{N}_{2}$. An online Shimadzu 2014 Gas Chromatography (GC) with three analyzing channels was used for full product analysis. The carbon balance was checked in each run and found to be higher than $95 \%$ in every case. The ethanol conversion and product selectivity were calculated on a per carbon basis and defined by two following equations: 


$$
\begin{aligned}
& \text { conversion }=\frac{\text { Ethanol }_{\text {in }}-\text { Ethanol }_{\text {out }}}{\text { Ethanol }_{\text {in }}} \times 100 \% \\
& \text { Swlectivity }=\frac{\text { Carbon in given product }}{\text { Carbon in all products }} \times 100 \%
\end{aligned}
$$

\section{Results and Discussions}

\subsection{Catalyst Characterization}

\subsubsection{XRD}

Figure 1 displays XRD profiles of ternary $\mathrm{A}_{1} \mathrm{Zn}_{1} \mathrm{Zr}_{8} \mathrm{O}_{\mathrm{n}}$ composite oxides in the comparison with binary $\mathrm{Zn}_{1} \mathrm{Zr}_{8} \mathrm{O}_{\mathrm{n}}$. Tetragonal phase of $\mathrm{ZrO}_{2}$ (PDF\#50-1089) are observed for all samples. But the details of the diffraction peaks change greatly with different A-site dopants. Binary $\mathrm{Zn}_{1} \mathrm{Zr}_{8} \mathrm{O}_{\mathrm{n}}$ only shows diffraction peaks from tetragonal phase of $\mathrm{ZrO}_{2}$. Sharper diffraction peaks of tetragonal $\mathrm{ZrO}_{2}$ are found over $\mathrm{Ni}_{1} \mathrm{Zn}_{1} \mathrm{Zr}_{8} \mathrm{O}_{\mathrm{n}}$, and some diffraction peaks assignable to $\mathrm{NiO}$ (PDF\#2901) are obvious. The introduction of Fe did not affect the diffraction peaks of tetragonal $\mathrm{ZrO}_{2} . \mathrm{Co}_{1} \mathrm{Zn}_{1} \mathrm{Zr}_{8} \mathrm{O}_{\mathrm{n}}$ shows the weak diffraction peaks of $\mathrm{CoO}$ species (PDF\#2902) and the peaks belonging to tetragonal $\mathrm{ZrO}_{2}$ remained unchanged. Although additional diffraction peaks are not found after introducing $\mathrm{Cr}$, it is noted that diffraction peaks of tetragonal $\mathrm{ZrO}_{2}$ are weakened. So, when binary $\mathrm{Zn}_{1} \mathrm{Zr}_{8} \mathrm{O}_{\mathrm{n}}$ composite oxides dope with a little of transition metal species, the changes depend on dopants. The introduction of Fe and Co species cannot affect the crystallinity. An opposite effection of the crystallinity is found when $\mathrm{Ni}$ and $\mathrm{Cr}$ are added. When $\mathrm{Ni}$ and $\mathrm{Co}$ are introduced, highly dispersed $\mathrm{Ni}$ and $\mathrm{Co}$ species were not formed. In this case, the bulk phase of $\mathrm{NiO}$ and $\mathrm{CoO}$ was formed in there two catalysts.

\subsection{2. $\mathrm{N}_{2}$ Adsorption-Desorption}

Figure 2 shows that all the catalysts display the type IV $\mathrm{N}_{2}$ absorption-desorption isotherms with $\mathrm{H} 3$ hysteresis loops at the relative pressure $\left(P / P_{0}\right)$ ranging from 0.80 to 1.0 , an indicative of a typical mesoporous structure. This indicates that the porous structure is not destroyed by doping. We also have calculated BET surface area $\left(S_{\mathrm{BET}}\right)$, pore volume $\left(V_{\mathrm{P}}\right)$ and pore diameter $\left(D_{\mathrm{P}}\right)$ from $\mathrm{N}_{2}$ absorption-desorption isotherms using BET and BJH models, and the results are shown in Table 1 . It can be seen that only introducing $\mathrm{Cr}$ improves the $S_{\mathrm{BET}}$ while other dopants introduced into the binary $\mathrm{Zn}_{1} \mathrm{Zr}_{8} \mathrm{O}_{\mathrm{n}}$ will cause the decrease of specific surface area.

\subsubsection{FESEM}

Figure 3 presents the FESEM chemical mapping image, which definitely shows the homogeneous distribution

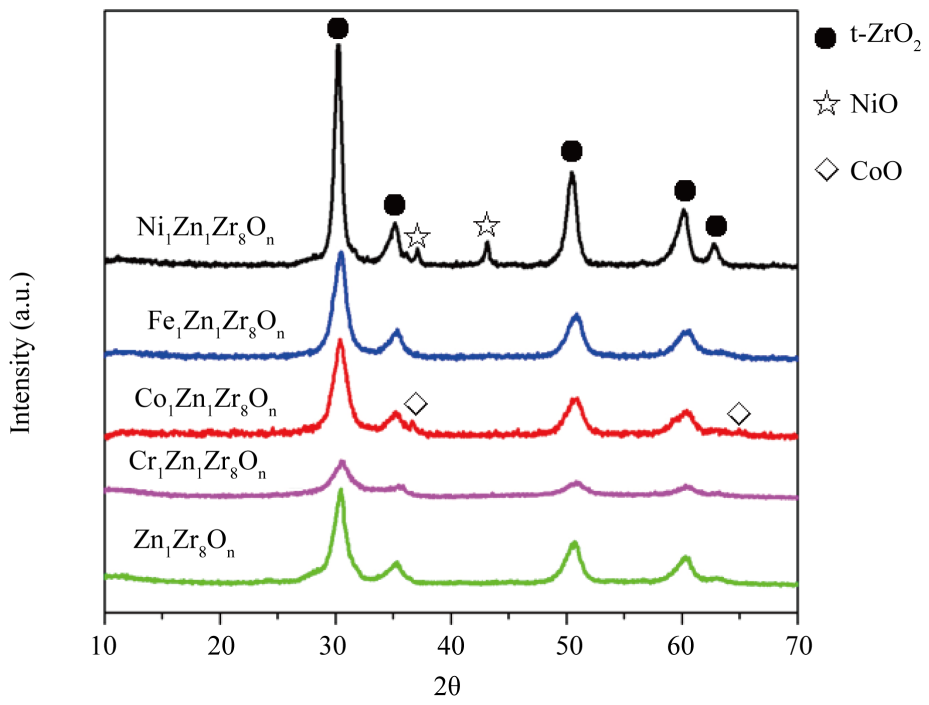

Figure 1. XRD patterns of $\mathrm{A}_{1} \mathrm{Zn}_{1} \mathrm{Zr}_{8} \mathrm{O}_{\mathrm{n}}$ and $\mathrm{Zn}_{1} \mathrm{Zr}_{8} \mathrm{O}_{\mathrm{n}}$ catalysts. 


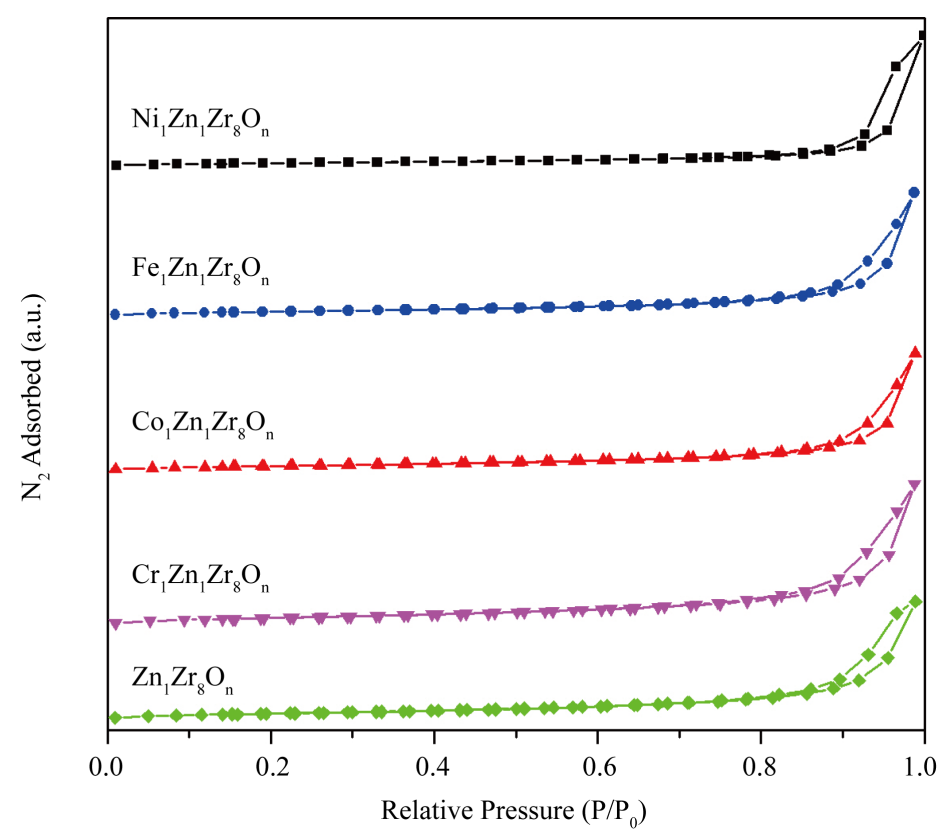

Figure 2. $\mathrm{N}_{2}$ adsorption-desorption isotherms of $\mathrm{A}_{1} \mathrm{Zn}_{1} \mathrm{Zr}_{8} \mathrm{O}_{\mathrm{n}}$ and $\mathrm{Zn}_{1} \mathrm{Zr}_{8} \mathrm{O}_{\mathrm{n}}$ catalysts.

Table 1. Physical and chemical properties of $\mathrm{A}_{1} \mathrm{Zn}_{1} \mathrm{Zr}_{8} \mathrm{O}_{n}$ catalysts.

\begin{tabular}{ccccc}
\hline Catalysts & $\mathrm{S}_{\mathrm{BET}}\left(\mathrm{cm}^{2} / \mathrm{g}\right)$ & $\mathrm{V}_{\mathrm{p}}\left(\mathrm{cm}^{3} / \mathrm{g}\right)$ & $\mathrm{D}_{\mathrm{p}}(\mathrm{nm})$ & Crystallite size $(\mathrm{nm})$ \\
\hline $\mathrm{Ni}_{1} \mathrm{Zn}_{1} \mathrm{Zr}_{8} \mathrm{O}_{\mathrm{n}}$ & 60.9 & 0.18 & 10.47 & 12.7 \\
$\mathrm{Fe}_{1} \mathrm{Zn}_{1} \mathrm{Zr}_{8} \mathrm{O}_{\mathrm{n}}$ & 87.5 & 0.60 & 10.50 & 9.3 \\
$\mathrm{Co}_{1} \mathrm{Zn}_{1} \mathrm{Zr}_{8} \mathrm{O}_{\mathrm{n}}$ & 87.7 & 0.57 & 9.47 & 9.2 \\
$\mathrm{Cr}_{1} \mathrm{Zn}_{1} \mathrm{Zr}_{8} \mathrm{O}_{\mathrm{n}}$ & 125.4 & 0.69 & 9.60 & 10.0 \\
$\mathrm{Zn}_{1} \mathrm{Zr}_{8} \mathrm{O}_{\mathrm{n}}$ & 106.6 & 0.43 & 8.19 & 10.6 \\
\hline
\end{tabular}
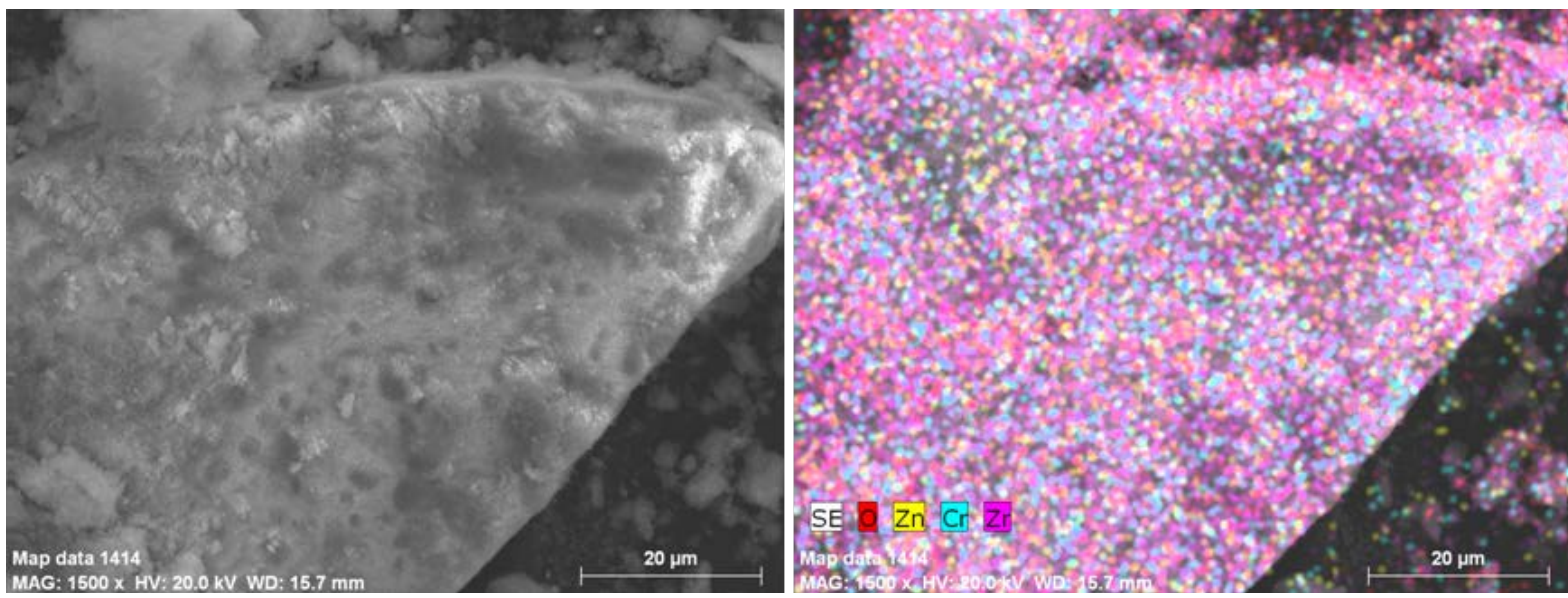

Figure 3. FESEM images corresponding element mapping of $\mathrm{Cr}_{1} \mathrm{Zn}_{1} \mathrm{Zr}_{8} \mathrm{O}_{\mathrm{n}}$ catalyst.

of $\mathrm{Cr}$ and $\mathrm{Zn}$ atoms with $\mathrm{Zr}$ and $\mathrm{O}$ atoms as a background, which support $\mathrm{XRD}$ results that the synthesized mixed metal oxides contain no individual $\mathrm{Cr}_{2} \mathrm{O}_{3}$ or $\mathrm{ZnO}$ phase. 


\subsection{Catalytic Performances}

Figure 4 presents the product distributions of ETIB reaction over ternary $\mathrm{A}_{1} \mathrm{Zn}_{1} \mathrm{Zr}_{8} \mathrm{O}_{\mathrm{n}}$ and binary $\mathrm{Zn}_{1} \mathrm{Zr}_{8} \mathrm{O}_{\mathrm{n}}$ catalysts at $500^{\circ} \mathrm{C}$. One can see that the selectivity of isobutene is $37 \%$ and $39 \% \mathrm{CO}_{2}$ is gained on binary $\mathrm{Zn}_{1} \mathrm{Zr}_{8} \mathrm{O}_{\mathrm{n}}$ catalysts. AsNi and Co is introduced forming $\mathrm{Ni}_{1} \mathrm{Zn}_{1} \mathrm{Zr}_{8} \mathrm{O}_{\mathrm{n}}$ and $\mathrm{Co}_{1} \mathrm{Zn}_{1} \mathrm{Zr}_{8} \mathrm{O}_{\mathrm{n}}$, respectively. There are no notable changes of product distribution with respect to binary $\mathrm{Zn}_{1} \mathrm{Zr}_{8} \mathrm{O}_{\mathrm{n}}$. But only acetone selectivity decreases or increases. When $\mathrm{Fe}$ is introduced forming $\mathrm{Fe}_{1} \mathrm{Zn}_{1} \mathrm{Zr}_{8} \mathrm{O}_{\mathrm{n}}$, isobutene selectivity (8\%) decreased dramatically which is far below binary $\mathrm{Zn}_{1} \mathrm{Zr}_{8} \mathrm{O}_{\mathrm{n}}$. In this case a lot of $\mathrm{CO}_{2}(62 \%)$ is generated, suggesting that the Fe species favors hydrogen production via steam reforming of ethanol $\left(\mathrm{CH}_{3} \mathrm{CH}_{2} \mathrm{OH}+\mathrm{H}_{2} \mathrm{O} \rightarrow \mathrm{CO}_{2}+\mathrm{H}_{2}\right)$. A large amount of $\mathrm{H}_{2}$ obtained in product effluents also supports this argument. In all ternary catalysts, $\mathrm{Cr}_{1} \mathrm{Zn}_{1} \mathrm{Zr}_{8} \mathrm{O}_{\mathrm{n}}$ shows the best isobutene selectivity (51\%), while the acetone selectivity increases to $12 \%$ and $\mathrm{CO}_{2}, \mathrm{CH}_{4}$ and ethylene selectivity decreases to $30 \%, 0.7 \%$ and $0.9 \%$ respectively, suggesting that ethanol dehydration and cracking are suppressed.

Reaction condition: catalyst weight $\mathrm{m}=0.20 \mathrm{~g} ; \mathrm{S} / \mathrm{C}=5 ; \mathrm{x}_{\text {ethanol }}=2.73 \mathrm{~mol} \%\left(\mathrm{~N}_{2}\right.$ balance $) ; \mathrm{W} / \mathrm{F}=0.0975$ $\mathrm{g} \cdot \mathrm{s} \cdot \mathrm{ml}^{-1}, \mathrm{P}=1 \mathrm{~atm} ., \mathrm{T}=500^{\circ} \mathrm{C}$.

As can be seen from Figure 5, the content of $\mathrm{ZnO}$ notably affected the product distribution of bioethanol conversion at $500^{\circ} \mathrm{C}$. When y value varies from 0 to 1 , ethylene selectivity decreases and isobutene selectivity increases greatly. At the same time, acetone selectivity increases firstly and then decreases. At $y=2$, isobutene selectivity decreases and ethylene shows up again. This suggests that the appropriate content of the zinc addition is very important to the good isobutene selectivity.

From above, we can conclude that the functionalized active sites associated with $\mathrm{A}, \mathrm{Zn}$ and $\mathrm{Zr}$ content in $\mathrm{A}_{1} \mathrm{Zn}_{\mathrm{y}} \mathrm{Zr}_{\mathrm{z}} \mathrm{O}_{\mathrm{n}}$ catalyst should be well matched to obtain the highest isobutene selectivity in ETIB reaction. Although the first step, ethanol dehydrogenation is not a difficult reaction, there is still the intense competition between ethanol dehydrogenation and dehydration. The introduction of transition metal species such as $\mathrm{Cr}$ can significantly promote the dehydrogenation and suppress the parallel competitive dehydration. The next steps (acetaldehyde-to-acetone and acetone-to-isobutene) need a proper balance between acid and basic sites, which have been evidenced by appropriate $\mathrm{Zn}$ addition. Because of the presence of single oxide, which is badly cooperated with other active sites, the introduction of $\mathrm{Co}$ or $\mathrm{Ni}$ cannot gain better isobutene selectivity. Especially, the introduction of Fe breaks the reaction path and leads to more by-products. Since $\mathrm{ZnO}$ is amphoteric oxide, and the excess or the insufficient of its addition will lead to other side reactions and cannot obtain good isobutene selectivity.

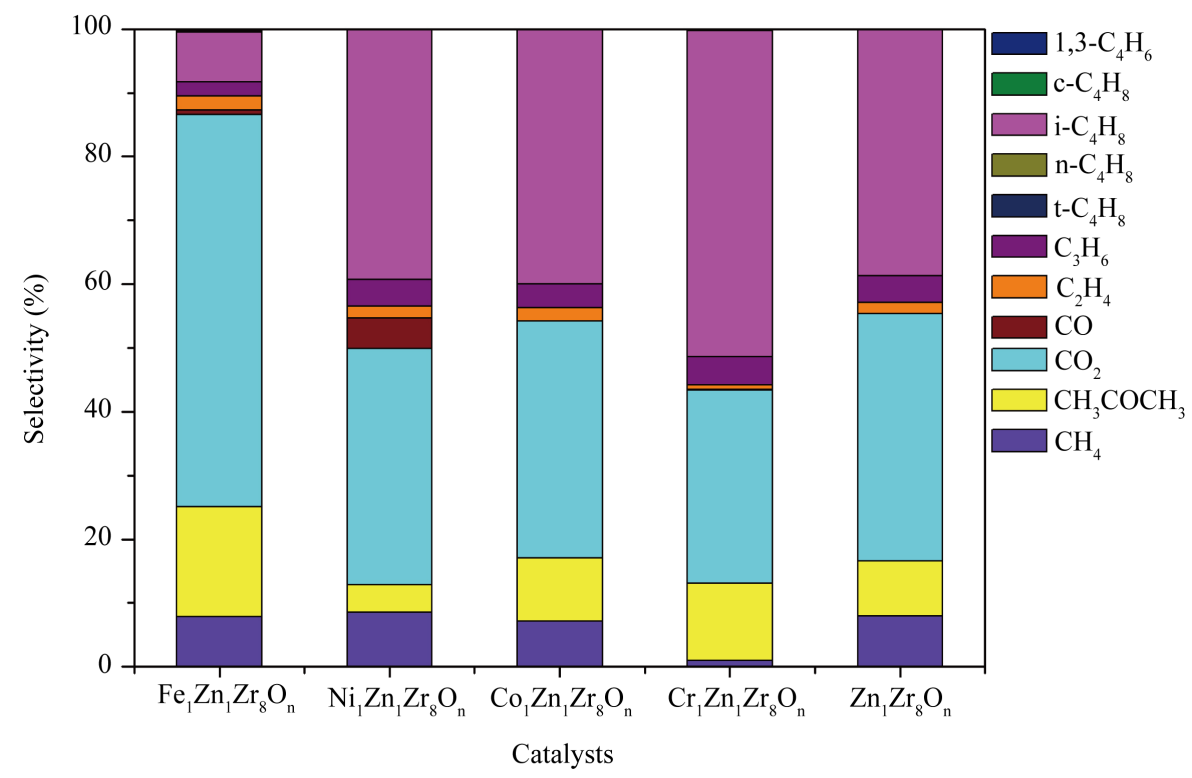

Figure 4. Product distribution of bio-ethanol conversion over $\mathrm{A}_{1} \mathrm{Zn}_{1} \mathrm{Zr}_{8} \mathrm{O}_{\mathrm{n}}$ and $\mathrm{Zn}_{1} \mathrm{Zr}_{8} \mathrm{O}_{\mathrm{n}}$ catalysts. Reaction condition: catalyst weight $\mathrm{m}=0.20 \mathrm{~g} ; \mathrm{S} / \mathrm{C}=5$; $\mathrm{x}_{\text {ethanol }}=2.73 \mathrm{~mol} \%\left(\mathrm{~N}_{2}\right.$ balance); $\mathrm{W} / \mathrm{F}=0.0975 \mathrm{~g} \cdot \mathrm{s} \cdot \mathrm{ml}^{-1}, \mathrm{P}=1 \mathrm{~atm} ., \mathrm{T}=500^{\circ} \mathrm{C}$. 


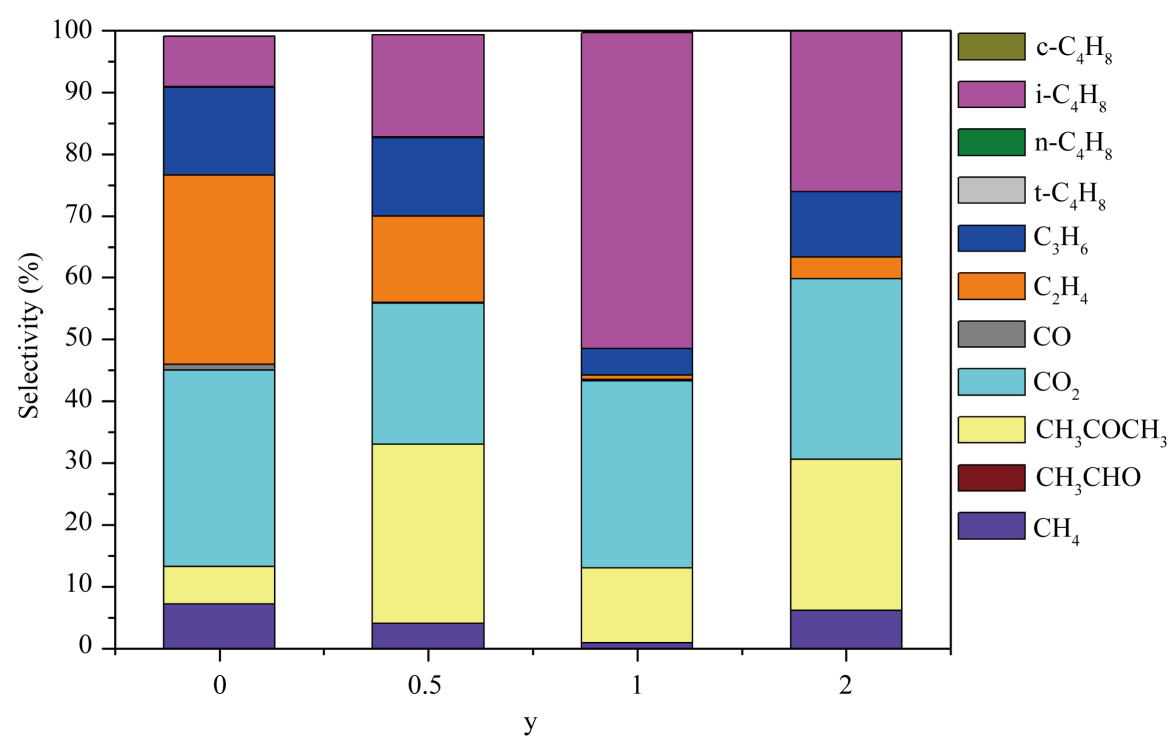

Figure 5. Product distribution of bioethanol conversion over $\mathrm{Cr}_{1} \mathrm{Zn}_{\mathrm{v}} \mathrm{Zr}_{8} \mathrm{O}_{\mathrm{n}}$ catalysts. Reaction condition: catalyst weight $\mathrm{m}=0.20 \mathrm{~g} ; \mathrm{S} / \mathrm{C}=5 ; \mathrm{x}_{\mathrm{ethanol}}=2.73 \mathrm{~mol} \%\left(\mathrm{~N}_{2}\right.$ balance $)$; $\mathrm{W} / \mathrm{F}=$ $0.0975 \mathrm{~g} \cdot \mathrm{s} \cdot \mathrm{ml}^{-1}, \mathrm{P}=1 \mathrm{~atm} ., \mathrm{T}=500^{\circ} \mathrm{C}$.

\section{Conclusion}

A series of ternary $A_{1} Z_{n} Z_{z} O_{n}$ catalysts using hard template method were synthesized and investigated for the activity of direct ETIB. Introduction of transition metal species into A-site of $\mathrm{Zn}_{\mathrm{y}} \mathrm{Zr}_{\mathrm{z}} \mathrm{O}_{\mathrm{n}}$ significantly affected the catalytic reactivity. In particular, introduction of Cr species into $\mathrm{Zn}_{1} \mathrm{Zr}_{8} \mathrm{O}_{\mathrm{n}}$ is essential for promoting ETIB activity with respect to binary $\mathrm{Zn}_{1} \mathrm{Zr}_{8} \mathrm{O}_{\mathrm{n}}$ which is closely related to excellent ethanol dehydrogenation capability caused by its redox properties. Meanwhile, appropriate addition of zinc on the catalyst surface is also essential for good isobutene yield. On the whole, the species and the quantity of active sites are the key to the target product isobutene.

\section{Acknowledgements}

This work is supported by The Program for Professor of Special Appointment (Eastern Scholar) at Shanghai Institutions of Higher Learning, National Natural Science Foundation of China (21503133), The Scientific Research Foundation for the Returned Overseas Chinese Scholars from State Education Ministry, Natural Science Foundation of Shanghai City (15ZR1419100), and Internal funds from Shanghai University of Engineering Science.

\section{References}

[1] Chheda, J.N., Huber, G.W. and Dumesic, J.A. (2007) Liquid-Phase Catalytic Processing of Biomass-Derived Oxygenated Hydrocarbons to Fuels and Chemicals. Angewandte Chemie International Edition, 46, 7164-7183. http://dx.doi.org/10.1002/anie.200604274

[2] Limayem, A. and Ricke, S.C. (2012) Lignocellulosic Biomass for Bioethanol Production: Current Perspectives, Potential Issues and Future Prospects. Progress in Energy \& Combustion Science, 38, 449-467. http://dx.doi.org/10.1016/j.pecs.2012.03.002

[3] Alvira, P., Tomás-Pejó, E., Ballesteros, M. and Negro, M.J. (2010) Pretreatment Technologies for an Efficient Bioethanol Production Process Based on Enzymatic Hydrolysis: A Review. Bioresource Technology, 101, 4851-4861. http://dx.doi.org/10.1016/j.biortech.2009.11.093

[4] Hahn-Hägerdal, B., Galbe, M., Gorwa-Grauslund, M.F., Lidén, G. and Zacchi, G. (2006) Bio-Ethanol—The Fuel of Tomorrow from the Residues of Today. Trends in Biotechnology, 24, 549-556. http://dx.doi.org/10.1016/j.tibtech.2006.10.004

[5] Chen, G., Li, S., Jiao, F. and Yuan, Q. (2007) Catalytic Dehydration of Bioethanol to Ethylene over $\mathrm{TiO}_{2} / \gamma-\mathrm{Al}_{2} \mathrm{O}_{3} \mathrm{Cat}_{-}$ 
alysts in Microchannel Reactors. Catalysis Today, 125, 111-119. http://dx.doi.org/10.1016/j.cattod.2007.01.071

[6] Han, Y., Lu, C., Xu, D., Zhang, Y., Yi, H. and He, H. (2011) Molybdenum Oxide Modified HZSM-5 Catalyst: Surface Acidity and Catalytic Performance for the Dehydration of Aqueous Ethanol. Applied Catalysis A General, 396, 8-13. http://dx.doi.org/10.1016/j.apcata.2010.12.040

[7] Varisli, D., Dogu, T. and Dogu, G. (2009) Novel Mesoporous Nanocomposite WOx-Silicate Acidic Catalysts: Ethylene and Diethylether from Ethanol. Industrial \& Engineering Chemistry Research, 48, 9394-9401. http://dx.doi.org/10.1021/ie8008154

[8] Nakajima, T., Tanabe, K., Yamaguchi, T., Matsuzaki, I. and Mishima, S. (1989) Conversion of Ethanol to Acetone over Zinc Oxide-Calcium Oxide Catalyst Optimization of Catalyst Preparation and Reaction Conditions and Deduction of Reaction Mechanism. Applied Catalysis, 52, 237-248. http://dx.doi.org/10.1016/0166-9834(89)80006-5

[9] Tago, T., Konno, H., Ikeda, S., Yamazaki, S., Ninomiya, W., Nakasaka, Y., Masuda, T., Konno, H., Ikeda, S. and Yamazaki, S. (2011) Selective Production of Isobutylene from Acetone over Alkali Metal Ion-Exchanged BEA Zeolites. Catalysis Today, 164, 158-162. http://dx.doi.org/10.1016/j.cattod.2010.10.034

[10] Sun, J., Zhu, K., Gao, F., Wang, C., Liu, J., Peden, C.H. and Wang, Y. (2011) Direct Conversion of Bio-Ethanol to Isobutene on Nanosized $\operatorname{Zn}(\mathrm{x}) \operatorname{Zr}(\mathrm{y}) \mathrm{O}(\mathrm{z})$ Mixed Oxides with Balanced Acid-Base Sites. Journal of the American Chemical Society, 133, 11096-11099. http://dx.doi.org/10.1021/ja204235v

[11] Sun, J. and Wang, Y. (2014) Recent Advances in Catalytic Conversion of Ethanol to Chemicals. ACS Catalysis, 4, 1078-1090. http://dx.doi.org/10.1021/cs4011343

[12] Angelici, C., Velthoen, M.E.Z., Weckhuysen, B.M. and Bruijnincx, P.C.A. (2014) Effect of Preparation Method and $\mathrm{CuO}$ Promotion in the Conversion of Ethanol into 1,3-Butadiene over $\mathrm{SiO}_{2}$-MgO Catalysts. Chemsuschem, 7, 25052515. http://dx.doi.org/10.1002/cssc.201402361

[13] Janssens, W., Makshina, E.V., Vanelderen, P., Houthoofd, K., Kerkhofs, S., Martens, J.A., Jacobs, P.A. and Sels, B.F. (2015) Ternary Ag/MgO: $\mathrm{SiO}_{2}$ Catalysts for the Conversion of Ethanol into Butadiene. Chemsuschem, 8, 913-913. http://dx.doi.org/10.1002/cssc.201500081

[14] Makshina, E.V., Janssens, W., Sels, B.F. and Jacobs, P.A. (2012) Catalytic Study of the Conversion of Ethanol into 1,3-Butadiene. Catalysis Today, 198, 338-344. http://dx.doi.org/10.1016/j.cattod.2012.05.031

\section{Submit or recommend next manuscript to SCIRP and we will provide best service for you:}

Accepting pre-submission inquiries through Email, Facebook, LinkedIn, Twitter, etc.

A wide selection of journals (inclusive of 9 subjects, more than 200 journals)

Providing 24-hour high-quality service

User-friendly online submission system

Fair and swift peer-review system

Efficient typesetting and proofreading procedure

Display of the result of downloads and visits, as well as the number of cited articles

Maximum dissemination of your research work

Submit your manuscript at: http://papersubmission.scirp.org/ 